\title{
Synthesis of some New 1,2,4,5-Tetrazine Derivatives Via Diels-Alder Reaction
}

\author{
Shaymaa K. Younis \\ Department of Chemistry \\ College of Science \\ Mosul University
}

Email : shaymaa_chemistry@yahoo.com

(Received 15 /7 / 2009 ; Accepted 7 / 12 / 2009)

\begin{abstract}
A rapid, sufficiency and economic with no pollution method was adopted to synthesize several 1-aryl-2,5-dione pyrrolidino[3,4-d]-3,6-diphenyl-3,4,5,6-tetrahydro pyridazino [1,2-a]-3,6-diaryl -1,2,3,6-tetrahydro-1,2,4,5-tetrazine compounds (4a-f) and (5af) using a solid phase (solvent-free ) microwave irradiation technique.

The reaction of dibenzylidine hydrazine (1a) as diaza-heterodiene with $\mathrm{N}$-aryl maleimide compounds (2a-f) as cyclic dienophile yielded the corresponding 1-aryl-2,5dione pyrrolidino[3,4-d]-3,6-diphenyl-3,4,5,6-tetrahydro pyridazine derivatives (3a-f) via Diels-Alder reaction that proceeded through intermolecular 1,4-cycloaddition mechanism and induced by microwave irradiation.

Similarly, compounds (3a-f) as cyclic hetero dienophile have been converted directly to the 1,2,3,6-tetrahydro-1,2,4,5-tetrazine derivatives (4a-f) and (5a-f) in presence of diarylidine hydrazines (1b-c) as diaza-heterodiene by means of Diels-Alder reaction induced by microwave irradiation and through intermolecular 1,4-cycloaddition mechanism too.

The reaction time has been brought down from hours to few minutes in this technique as compared with the conventional method. This method was, also, efficient, fast economic and environmental friendly.

All the prepared compounds were confirmed by the available physical and spectral methods.

Key words : Diarylidine hydrazine compounds, microwave irradiation, Diels-Alder reaction, 1,2,4,5-tetrazine compounds and pyridazine compounds.

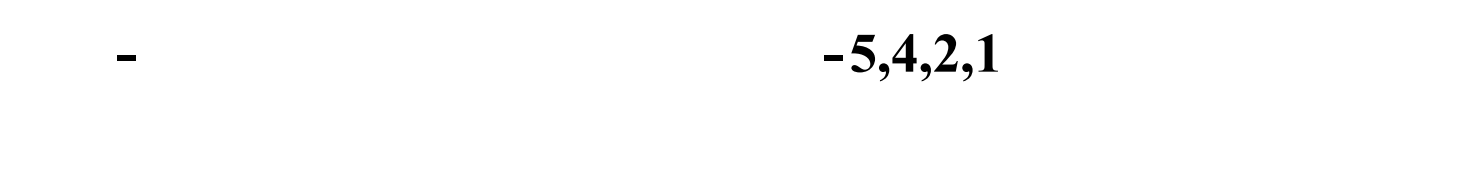

مُ تبني طريقةسربعة وكفؤة واقتصاية وغير ملوثة للبيئة لتحضير عدد من مركبلت 1 -اريل -

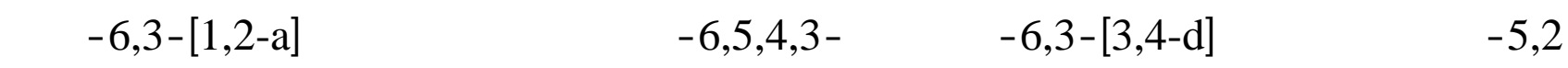

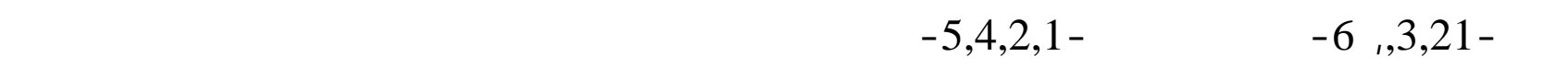




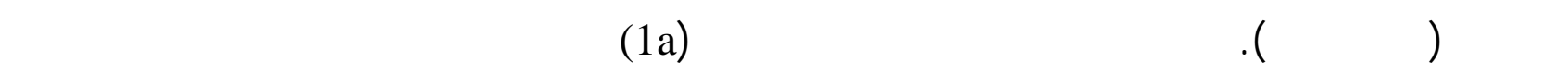

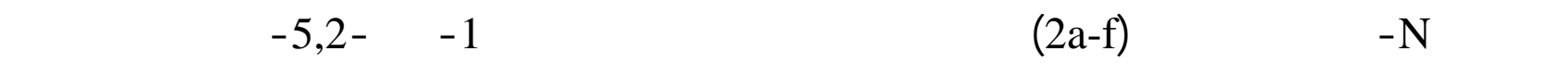

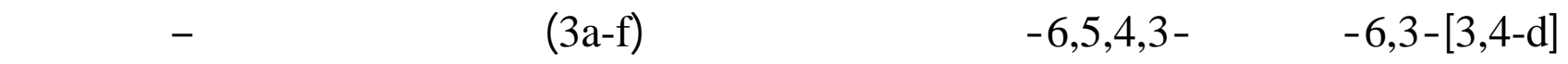

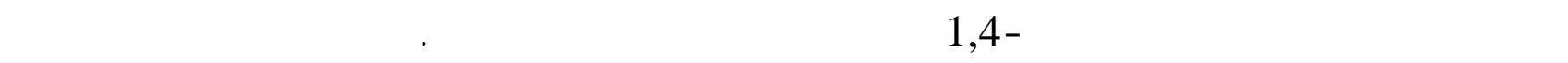
مبلثر تحويل المركببت (3a-f) كداليذوفيلات حلقية غير متجلنة وبوجود المركبلت (1b-c) كدليينات غير

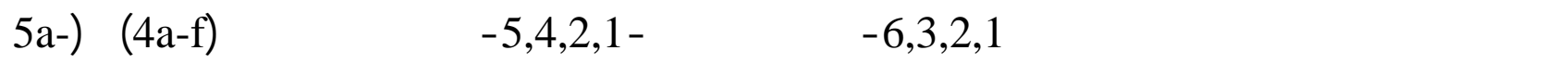

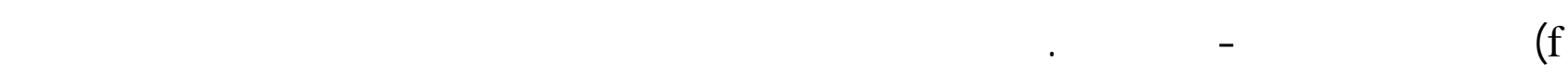

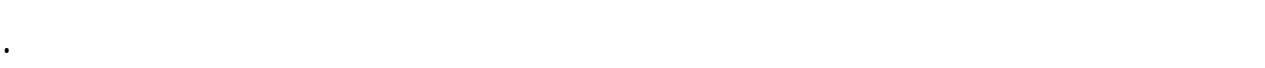
شخصت جمبع المركبلت المحضرة بلستخدلم الطارايق الفيزياوية و الطيفية المتوفرة.

الكامل الفتلحية: - مركبلت ثنائي اريليين هيدرازين, ققنية التشعبع بالموجلت الدققة, تفاعل ديلز - الدر, مركبت البيريدايازين, مركبلت 5,4,2,1 - تيترازين. 